\title{
Araștırma Makalesi \\ Bitkisel ve Hayvansal Proteinlerin Eriştenin Tekstürel ve Duyusal Özelliklerine Etkisi
}

\author{
Meryem GÖKSEL SARAÇ ${ }^{1}$
}

\section{ÖZ}

Bu çalışmada farklı bitkisel (soya, bezelye ve buğday) ve hayvansal (peynir altı suyu ve yumurta ak1) proteinlerin erişte üretiminde kullanılmasının, eriştenin fizikokimyasal, tekstürel, pişirme ve duyusal özelliklerinde oluşturduğu etkilerin belirlenmesi amaçlanmıştır. Bu amaçla $\% 80$ protein içeriğine sahip bitkisel ve hayvansal protein tozları erişte üretiminde kullanılmıştır. Duyusal analiz değerlendirmesinde TOPSİS yöntemi uygulanmıştır. Pişirme işlemi sonucu en yüksek protein içeriği bezelye (\%36.23) ve soya (\%30.00) ile üretilen eriştelerde belirlenirken, tekstür analizinde en sert ürün yumurta akı (13616.12 g) ile üretilen erişte olarak tespit edilmiştir. TOPSíS değerlendirmesi sonucu en çok tercih edilen ürün peynir altı suyu proteini ile üretilen erişte olurken en az tercih edilen ürün ise yumurta akı ile üretilen erişte olmuştur.

Anahtar Kelimeler: Bitkisel protein, erişte, hayvansal protein, tekstür, TOPSİS

\section{The Effect of Vegetable and Animal Proteins on Textural and Sensory Properties of Noodles}

\begin{abstract}
In this study, it was aimed to determine the effects of using different vegetable (soy, pea and wheat) and animal (whey and egg white) proteins in noodle production on physicochemical, textural, cooking and sensory properties of noodles. For this purpose, animal and vegetable protein powders has $80 \%$ protein content were used in the production of noodles. TOPSIS application was used in the sensory analysis evaluation. As a result of the cooking process, the highest protein value was determined in noodles produced with pea $(36.23 \%)$ and soy $(30.00 \%)$ proteins, while the hardest product was determined as noodles produced with egg white protein $(13616.12 \mathrm{~g})$ in texture analysis. As a result of the TOPSIS evaluation, the most preferred product was noodle produced with whey protein, while the least preferred was the noodle produced with egg white protein.
\end{abstract}

Keywords: Animal protein, noodles, texture, TOPSIS, vegetable protein

ORCID ID (Yazar sirasına göre)

0000-0002-8190-2406

\footnotetext{
Yayın Kuruluna Geliş Tarihi: 21.01.2021

Kabul Tarihi: 11.02.2021

${ }^{1}$ Sivas Cumhuriyet Üniversitesi, Yıldızeli Meslek Yüksekokulu, Gıda Teknolojisi, Sivas

E-posta:mgoksel@cumhuriyet.edu.tr
} 


\section{Giriș}

Erişte ve benzeri ürünler tahıl bazlı, tüketim oranı yüksek, taşıma, depolama, pişirme kolaylığı olan ve besinsel özellikleri nedeniyle tercih edilen geleneksel ürünlerdir (Petitot ve ark., 2009; Akillioglu ve Yalcin, 2010). Erişte geleneksel yöntemlerle ve son dönemlerde ticari olarak un, su ve tuz karışımı ile üretilmektedir. Bazı bölgelerde süt ve yumurta da ürün formülasyonuna katılmaktadır. Farklı ebatlarda kesilen ve firında ya da güneşte kurutma gibi teknikler kullanılarak üretilen erişte dünya genelinde ve Türkiye'de tercih edilen bir hazır gıdadır (Özkaya ve ark., 2001; Bilgiçli, 2009). Erişte üretiminde kullanılan malzemeler istenilen doku ve lezzet parametrelerinin olușumuna katkı sağlamaktadır. Yaygın kullanım oranı ile erişte formülasyonuna katılan yumurta sahip olduğu protein miktarı sayesinde hamurun şekil alma özelliğini, pişmiş üründe ise esnekliği desteklemektedir (Alamprese ve ark., 2005). Ayrıca erişte kalitesinin değerlendirilmesi üzerinde yapılan çalışmalar, protein içeriğinin tekstürel özellikleri etkilediğini göstermektedir (Kruger ve ark., 1994). Erişte genellikle geleneksel yöntemler kullanılarak üretilmektedir. Geleneksel üretimde erişte formülasyonunda ve üretilen erişteye uygulanacak pişirme tekniğinde farklılıklar gözlenmektedir. $\mathrm{Bu}$ farklilıklar nedeniyle erişteler duyusal, besinsel ve kalite özellikleri açısından yöresel olarak özelleşmektedir (Woo ve Seib, 2002; De Zorzi ve ark., 2007). Ayrica erişteler karbonhidrat bakımından zengin olmaları nedeniyle protein, vitamin ve mineral açısından fakir ürünler olarak tanımlanmaktadırlar. $\mathrm{Bu}$ nedenle beslenme düzeninde, erişte tüketiminin yanı sıra proteince zengin ürünlerinde menülere eklenmesi önerilmektedir (Eyidemir ve Hayta, 2009; Aktaş ve Türker, 2015). Bu yaklaşımlar göz önüne alınarak son dönemlerde yapılan çalışmalar eriştenin besinsel, duyusal ve tekstürel özelliklerini iyileştirmek amacıyla kurgulanmaktadır. Bu kapsamında chia (Levent, 2017), üzüm, nar ve kuşburnu tohumu (Koca ve ark., 2018), mercimek, bakla, nohut ve fasülye (Levent ve Yeşil, 2019), karabuğday (Bilgiçli, 2009), kinoa, amarant ve karabuğday (Öncel ve Demir, 2019) unları gibi alternatif un kaynaklarının kullanıldığı çalışmaların yanı sıra emülgatör ve gluten (Bilgiçli ve ark., 2011), rüșeym ve $\beta$-glukan (Aktaş ve ark., 2015), süt endüstrisi yan ürünleri (Aktaş ve Türker, 2015), pirinç kepeği (Tuncel ve ark., 2017), kavun çekirdeği tozu (Çelik ve Pozan, 2020) gibi katkı maddelerinin etkilerinin araştırıldı 1 çalışmalarda yapılmaktadır.

Son dönemlerde sağlıklı beslenme yönündeki eğilimler ile vegan, vejeteryan ve sporcu beslenme tarzları tercih edilmektedir. Protein oranı arttırılmış ya da bitkisel protein kaynakları ile zenginleştirilmiş ürünlere olan ilgi de bu doğrultuda artış göstermektedir. Ayrıca gıda ürünlerinde protein ilavesinin besinsel değerde artış ve ürün formunda iyileştirmeler meydana getirmenin yanında bireylerde uzun süreli tokluk hissi sağladığı da bilinmektedir (Veldhorst ve ark., 2008). Öte yandan özellikle gluten proteinleri başta olmak üzere protein ilavesinin hamur ve erişte kalitesi üzerinde olumlu etkilerinin olduğu bilinmektedir ( $\mathrm{Li}$ ve ark., 2014).

$\mathrm{Bu}$ çalışma kapsamında tüketimi oldukça fazla olan eriştelere buğday, yumurta akı, soya, bezelye ve peynir altı suyu proteinleri ilave edilerek ürün yapısında meydana gelen etkiler fizikokimyasal, tesktürel ve pişirme özellikleri açısından incelenmiştir. Ayrıca farklı protein kaynaklarının son üründe oluşturacağı etkiler duyusal açıdan da değerlendirilmiş ve en çok tercih edilen ürün Çok Kriterli Karar Verme Tekniklerinden biri olan TOPSİS yöntemi ile belirlenmiştir.

\section{Materyal ve Yöntem \\ Erişte Üretimi}

Çalışma kapsamında kullanılan yumurta akı, bezelye, soya, buğday ve peynir altı suyu proteinleri (Alfasol, Türkiye) $\% 80$ oranında protein içermektedir. Erişte üretiminde hamur formülasyonunda $1000 \mathrm{gr}$ un, $15 \mathrm{gr}$ tuz ve $100 \mathrm{gr}$ protein kullanılmıştır. Bütün hammaddeler eklendikten sonra hamur yoğurma makinas1 yardımiyla (Schafer, W.b. Prochef Xl Stand Mikser, Almanya) $10 \mathrm{dk}$ süreli yoğurma işlemi gerçekleştirilmiştir. Yoğurma işlemi tamamlandıktan sonra $20 \mathrm{dk}$ süre ile hamurda 
dinlendirme yapılmıştır. Erişte kesme makinasina (Marcato Atlas 150 Roller, İtalya) uygun şekilde inceltilen hamurlar kesme işlemi sonunda $0.60 \mathrm{~cm}$ kalınlıkta ince şeritler halinde elde edilmiştir (Dirim ve Çalışkan, 2017). Farklı protein kaynakları ile üretilen erişteler oda sicaklığında kurutulmuş ve analiz süresine kadar kilitli polietilen poşetlerde yine oda sicaklığında depolanmıştır. Yumurta akı (YAPE), bezelye (BEPE), soya (SOPE), buğday (BUPE) ve peynir alt1 suyu (PSPE) proteinleri ile üretilen eriştelerin çiğ ve pişmiş halleri Şekil 1'de görülmektedir.

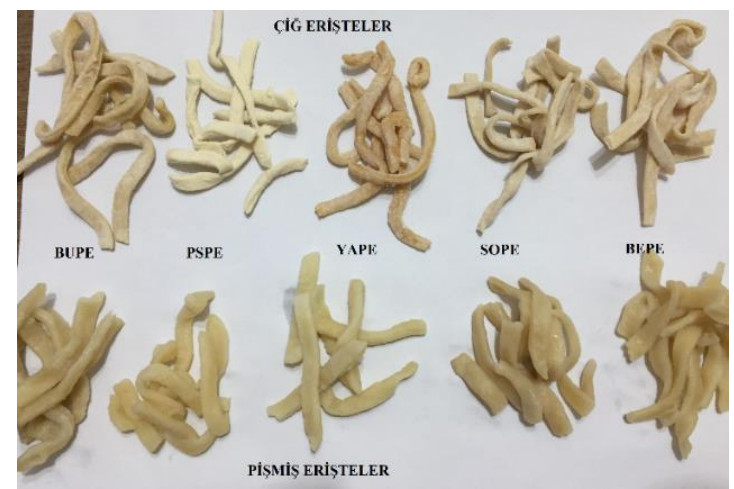

Şekil 1. Farklı proteinler ile üretilmiş erişte örnekleri

\section{Fizikokimyasal Analizler}

Farklı protein kaynakları ile üretilmiş erişte örneklerinin nem, kül ve protein miktarları AOAC (2005) yöntemlerine göre gerçekleştirilmiştir. Erişte örneklerinin kül miktarları kül fırınında (Nükleon NKF, Türkiye) krozelere tartılan erişte örneklerinin 12 saat yakılmasıyla, nem tayinleri ise etüvde (Nüve, MF120, Turkey) $105^{\circ} \mathrm{C}$ 'de kurutma işleminin sabit tartıma gelmesi için gerekli süre sonunda belirlenmiştir. Protein tayini için kjeldahl yöntemi uygulanmış ve erişte örneklerinin pişirme işlemi sonrası tüketime hazır haldeki formlarında kalan protein miktarları hesaplanmıştır. Protein değişiminin çiğ ve pişmiş erişte örneklerinde oluşturduğu etkiler renk değerleri açısında da incelenmiştir. Eriştelerin renk karakteristiği renk ölçüm cihazıyla (Minolta Spectrophotometer CM3600d, Japonya) CIE renk skalası baz alınarak $L^{*}, a^{*}$ ve $b^{*}$ değerleri ile tespit edilmiştir.

\section{Pișirme Özellikleri}

Erişte örneklerinin ilk olarak pişme süreleri belirlenmiştir. $\mathrm{Bu}$ amaçla $200 \mathrm{ml}$ kaynayan suyun içerisine 10 gr erişte örneği ilave edilmiş ve pişme süreleri eriştelerin tamamen yumuşaması için geçen süre takip edilerek saptanmıştır (AACC, 2009). Su bağlama analizi için 10 gr erişte örneği pişme süresi sonunda süzülmüş ve tartılmıştır. Analiz sonucu pişmiş erişte ağırlığı (PEA) değeri kullanılarak denklikte yer alan formül ile hesaplanmıştır (Lai, 2002).

$$
\text { Su Bağlama }(\%)=\frac{(P E A-10)}{10} \times 100
$$

Pişme kaybı analizinde su bağlama analizi için uygulanan pişirme yöntemi kullanılmış ve süzme işlemi sonucunda elde edilen erişte pişirme suyundan $10 \mathrm{ml}$ alınarak sabit tartıma gelene kadar etüvde kurutulmuştur. Kurutma işlemi sonrası pişirme suyundaki kuru kalıntı ağırlığı (KKA) belirlenmiştir. Eriştelerin pişme kayb1 değerleri formül kullanılarak hesaplanmıştır (Lai, 2002).

$$
\text { Pişme Kaybı }(\%)=\frac{K K A}{10} x 100
$$

Hacim artışı analizinde ise 10 gr pişmiş ve çiğ erişte örneği içinde $200 \mathrm{ml}$ su bulunduran mezüre atılmış ve hacimde meydana getirdikleri değişimler tespit edilmiştir. Çiğ erişte $\left(\mathrm{V}_{\text {çĭg }}\right)$ pişmiş erişte $\left(\mathrm{V}_{\text {pişmiş }}\right)$ hacimleri formüle eklenerek hacim artışı değeri hesaplanmıştır (AACC, 2009).

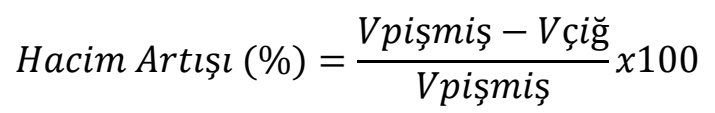

\section{Tekstür Analizi}

Protein çeşit değişimin erişteler üzerinde tekstürel açıdan oluşturduğu etkilerin belirlenmesi için erişteler çiğ ve optimum sürelerinde pişirilmiş olarak analiz edilmişlerdir. Tekstür analizi için tekstür ölçüm cihazı (T.A.HD Plus Stable Micro Systems, İngiltere) ve çiğ erişteler için 5 Blade Kramer Cell ve HDP/KS5, pişmiş erişteler için P/36R cihaz başlığı kullanılmıştır. Çiğ erişte örnekleri sıkılık (kg) ve toplam kesme kuvveti (kg.sn) değerleri 
için $2.00 \mathrm{~mm} / \mathrm{sn}$ test hızı ve $\% 75$ gerinim şartları kullanılmıştır. Pişmiş erişteler ise sertlik (g) ve yapışkanlık (g.sn) değerleri için $2.00 \mathrm{~mm} / \mathrm{sn}$ test hızl, $10 \mathrm{~mm} / \mathrm{sn}$ son test ve $72 \mathrm{~mm}$ mesafe analiz şartlarında incelenmiştir. Çalışma kapsamında bütün analizler 2 paralel ve 3 tekrar şeklinde gerçekleştirilmiştir.

\section{Duyusal Analizler}

Erişte örneklerinin duyusal analizinde çiğ ve pişmiş erişteler kullanılmıştır. Analiz Aktaş ve Türker, (2015) tarafindan kullanılan duyusal değerlendirme teknikleri modifiye edilerek gerçekleştirilmiştir. Çalışmada duyusal analiz teknikleri konusunda eğitimli ve sigara kullanmayan 25 kişi panel grubunu oluşturmuş ve panelistler analiz öncesi bilgilendirilmişlerdir. Duyusal analizler duyusal analiz laboratuvarlarında gerçekleştirilmiştir. Analiz 1 en kötü, 9 en iyi olacak şekilde tasarlanmış ve değerlendirmeleri 1-9 puan aralığı kullanılarak panel raporlarına kaydedilmiştir. Panelde çiğ erişte örnekleri renk, kırılganlık ve görünüş, pişmiş erişte örnekleri ise renk, sertlik, yapışkanlık, çiğnenebilirlik, tataroma ve genel beğeni kriterleri açısından değerlendirilmiştir.

\section{TOPSİS Yöntemi}

TOPSİS çok kriterli karar verme tekniklerinden biridir ve son dönemlerde birçok alanda karar verme yöntemi olarak kullanılmaktadır. Uygulama 6 temel aşamadan oluşmaktadır. Çalışma kapsamında pişmiş erişte örneklerinin duyusal değerlendirme kriterlerinden çiğnenebilirlik, tat-aroma, yapışkanlık ve sertlik değerleri panelistlerin yaptığı önem siralamasına göre belirlenmiş ve değerlendirilmiştir. Analiz kapsamında yapılacak değerlendirmenin karar hiyerarşi grafiği Şekil 2'de gösterilmektedir.

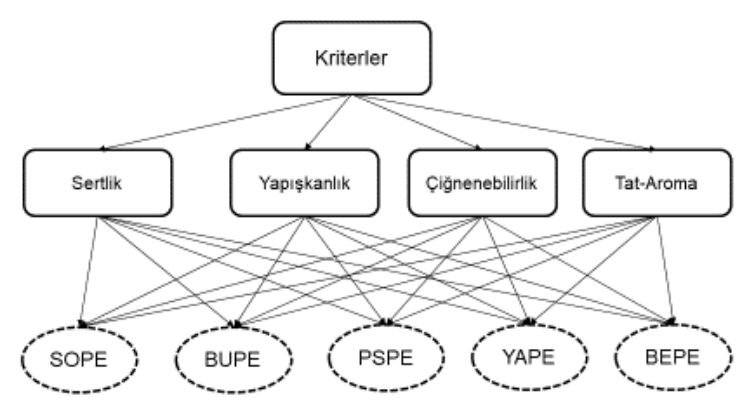

Şekil 2. Eriştelerin TOPSíS değerlendirmesi için hiyerarşi karar süreci

İlk aşamada karar matrisi formül kullanılarak normalize edilir ve normalize karar matrisi $\left(r_{i j}\right)$ oluşturulur (Dogan ve ark., 2016; Gökdalay, 2009).

$$
r_{i j}=\frac{a_{i j}}{\sqrt{\sum_{k=1}^{m} a_{k j}^{2}}}
$$

İkinci aşamada normalize edilmiş karar matrisi formül kullanılarak ağırlıklandırılır ve ağırlıklandırılmış karar matrisi $\left(Y_{i j}\right)$ oluşturulur.

$$
Y_{i j}=\left[\begin{array}{cccc}
w_{1} x_{11} & w_{2} x_{12} & \ldots & w_{n} x_{1 n} \\
w_{1} x_{21} & w_{2} x_{22} & \ldots & w_{n} x_{2 n} \\
\cdot & & & \cdot \\
\cdot & & & \cdot \\
\cdot & & & \cdot \\
w_{1} x_{m 1} & w_{2} x_{m 2} & \ldots & w_{n} x_{m n}
\end{array}\right]
$$

Üçüncü bölümde pozitif $\left(\mathrm{A}^{*}\right)$ ve negatif $\left(\mathrm{A}^{-}\right)$ ideal çözümler ağırlıklandırılmış normalize değerler (v) kullanılarak belirlenir.

$$
\begin{aligned}
A^{*} & =\left\{v_{1}^{*}, v_{2}^{*}, \ldots, v_{n}^{*}\right\} \\
A^{-} & =\left\{v_{1}^{-}, v_{2}^{-}, \ldots, v_{n}^{-}\right\}
\end{aligned}
$$


Dördüncü aşamada alternatiflerin pozitif ve negatif ideal çözümden uzaklığ 1 aşağıdaki formüller kullanılarak hesaplanır. Burada $D_{i}^{*}$ pozitif ideal çözüme uzaklığı $D_{i}^{-}$ise negatif ideal çözüme uzaklığ ifade etmektedir.

$$
\begin{aligned}
& D_{i}^{*}=\sqrt{\sum_{j=1}^{n}\left(v_{i j}-v_{j}^{*}\right)^{2}} \\
& D_{i}^{-}=\sqrt{\sum_{j=1}^{n}\left(v_{i j}-v_{j}^{-}\right)^{2}}
\end{aligned}
$$

Beşinci basamakta her bir alternatif için ideal çözüme göre yakınlık değeri formül ile hesaplanır.

$$
R_{i}^{*}=\frac{D_{i}^{-}}{D_{i}^{-}+D_{i}^{*}}
$$

Son aşamada ise belirlenen yakınlık değerleri her bir erişte örneği için büyükten küçüğe doğru sıralanmıș ve duyusal değerlendirme verileri ile seçilen kriterler açısından en çok tercih edilen örnek tespit edilmiştir.

\section{İstatistiksel Analizler}

Çalışma sonunda verilerin değerlendirilmesi ve ortalamalar arasındaki farkın belirlenmesi için tek yönlü varyans analizi (ANOVA) ve Tukey'in HSD testi SPSS Statistics 17.0 paket programı kullanılarak yapılmıştır. Analiz sonucunda $\mathrm{p}<0.05$ değeri anlamlı olarak kabul edilmiştir.

\section{Bulgular ve Tartışma Fizikokimyasal Analizler \\ Farklı protein kaynakları ile üretilmiş erişte örneklerinin nem, kül ve protein değerleri Çizelge 1'de gösterilmiştir.}

Çizelge 1. Çiğ eriştelerin nem ve kül, pişmiş eriştelerin protein değerleri

\begin{tabular}{cccc}
\hline & Nem Miktar1 (\%) & Kül Miktar1 (\%) & Protein Miktar1 (\%) \\
\hline SOPE & $8.03 \pm 1.38^{\mathrm{a}}$ & $0.81 \pm 0.43^{\mathrm{c}}$ & $30.00 \pm 0.99^{\mathrm{b}}$ \\
BUPE & $8.06 \pm 1.10^{\mathrm{a}}$ & $1.04 \pm 0.06^{\mathrm{b}}$ & $20.07 \pm 1.13^{\mathrm{d}}$ \\
PSPE & $8.00 \pm 0.96^{\mathrm{a}}$ & $1.59 \pm 0.13^{\mathrm{a}}$ & $24.01 \pm 1.11^{\mathrm{c}}$ \\
YAPE & $8.10 \pm 1.10^{\mathrm{a}}$ & $1.05 \pm 0.17^{\mathrm{b}}$ & $23.91 \pm 1.02^{\mathrm{c}}$ \\
BEPE & $8.07 \pm 1.00^{\mathrm{a}}$ & $0.81 \pm 0.21^{\mathrm{c}}$ & $36.23 \pm 1.00^{\mathrm{a}}$
\end{tabular}

*Aynı sütundaki farklı küçük harfle belirtilen değerlerin istatistiksel olarak önemli ölçüde farklı olduğunu belirtmektedir. $\mathrm{p}<0.05$. ortalama \pm ; standart sapma

Çiğ erişte örneklerinin nem içeriği \% 8.00-8.10 aralığında belirlenmiștir ve örneklerinin nem değerleri arasında istatistiksel açıdan bir fark bulunamamıştır $\quad(\mathrm{p}>0.05)$. Örneklerin kül içerikleri incelendiğinde $\% 0.81$ kül içeriğine sahip SOPE ve BEPE örneklerinin en düşük, $\% 1.59$ kül oranı ile PSPE örneğinin en yüksek kül değerine sahip olduğu belirlenmiştir. Öte yandan yumurta akı ve buğday proteini ile üretilmiş eriştelerin kül miktarları arasında fark bulunmamıştır $(\mathrm{p}>0.05)$. Farklı protein çeşitleri ile üretilen erişte örneklerinin pişirme işlemi sonucu yapısında kalan protein miktarlarının belirlenmesi ve tüketici grupları tarafindan tercih edildikleri takdirde ne kadar protein alacaklarını tespit etmek için protein analizi gerçekleştirilmiştir. Pişmiş eriştelerin protein oranları \% 20.03-36.23 aralığında belirlenmiştir. En yüksek protein oranı bezelye proteini ile üretilen BEPE kodlu örnekte tespit edilmiştir. PSPE ve YAPE örneklerinin protein değerleri arasında ise fark bulunamamıştır $(\mathrm{p}>0.05)$. Ayran tozu, peynir altı suyu, peynir altı suyu protein konsantresi ve $\beta$-Glukan ilavesi ile üretilen eriştelerde nem içeriğinin \%7.94-9.05, kül miktarının ise \%1.17-1.83 aralığında tespit 
edildiği çalıșmada protein miktarının ayran tozu ve peynir altı suyu protein konsantresi ilavesi ile arttığı belirlenmiştir (Aktaş ve Türker, 2015).
Erişte örneklerinin çiğ ve pişmiş yapılarının renk değerleri Çizelge 2'de gösterilmiştir. Çiğ erişte örneklerinin $L^{*}$ değerleri 63.87-73.20 aralığında belirlenmiştir.

Çizelge 2. Çiğ ve pişmiş erişte örneklerinin renk değerleri

\begin{tabular}{lllllll}
\hline & \multicolumn{3}{c}{ Çĭ̆ Erişte } & \multicolumn{3}{c}{ Pişmiş Erişte } \\
\cline { 2 - 7 } & $L^{*}$ & $a^{*}$ & $b^{*}$ & $L^{*}$ & $a^{*}$ & $b^{*}$ \\
\hline SOPE & $66.67 \pm 0.70^{\mathrm{b}}$ & $3.51 \pm 0.01^{\mathrm{b}}$ & $15.92 \pm 0.02^{\mathrm{a}}$ & $67.48 \pm 0.35^{\mathrm{c}}$ & $2.14 \pm 0.05^{\mathrm{a}}$ & $19.09 \pm 0.01^{\mathrm{b}}$ \\
BUPE & $64.98 \pm 0.76^{\mathrm{c}}$ & $3.11 \pm 0.01^{\mathrm{b}}$ & $15.87 \pm 0.16^{\mathrm{a}}$ & $71.06 \pm 0.14^{\mathrm{b}}$ & $1.82 \pm 0.01^{\mathrm{b}}$ & $20.42 \pm 0.06^{\mathrm{a}}$ \\
PSPE & $73.20 \pm 0.01^{\mathrm{a}}$ & $1.57 \pm 0.04^{\mathrm{c}}$ & $15.32 \pm 0.14^{\mathrm{a}}$ & $76.43 \pm 0.44^{\mathrm{a}}$ & $0.79 \pm 0.01^{\mathrm{d}}$ & $20.30 \pm 0.02^{\mathrm{a}}$ \\
YAPE & $63.87 \pm 0.05^{\mathrm{c}}$ & $5.15 \pm 0.06^{\mathrm{a}}$ & $15.08 \pm 0.02^{\mathrm{a}}$ & $64.05 \pm 0.67^{\mathrm{d}}$ & $0.80 \pm 0.07^{\mathrm{d}}$ & $19.75 \pm 0.23^{\mathrm{b}}$ \\
BEPE & $67.52 \pm 0.66^{\mathrm{b}}$ & $3.93 \pm 0.04^{\mathrm{b}}$ & $15.57 \pm 0.09^{\mathrm{a}}$ & $70.27 \pm 0.04^{\mathrm{b}}$ & $1.49 \pm 0.04^{\mathrm{c}}$ & $20.35 \pm 0.16^{\mathrm{a}}$ \\
\hline
\end{tabular}

*Aynı sütundaki farklı küçük harfle belirtilen değerlerin istatistiksel olarak önemli ölçüde farklı olduğunu belirtmektedir. $\mathrm{p}<0.05$. ortalama \pm ;standart sapma

Pişmiş erişte örneklerinin renk değerleri

YAPE ve BUPE örnekleri en düşük $L^{*}$ değerine sahip örnekler olmuş ve aralarında bir fark bulunamamıştır. Öte yandan en yüksek değer PSPE örneğinde belirlenmiștir. Renk değerlendirmelerinde $L^{*}$ değerinin sifira yaklaşması örnekte siyah renk göstergesi iken 100'e yaklaşma beyazlık ifadesi olarak tanımlanmaktadır. $\mathrm{Bu}$ nedenle çiğ erişte örneklerinde en yüksek beyazlık göstergesine sahip ürün peynir altı suyu proteini ile üretilen ürün olarak saptanmıştır. $+a^{*}$ değerinin kırmızıyı, $-a^{*}$ ise yeşili ifade ettiği $a^{*}$ değerleri çiğ erişte örneklerinde 1.57-5.15 aralığında belirlenirken en düşük değer PSPE, en yükssek değer ise YAPE eriştesinde tespit edilmiştir. Ayrıca SOPE, BUPE ve BEPE örneklerinin $a^{*}$ değerleri açısından aralarında bir fark belirlenememiştir $(\mathrm{p}>0.05)$. Diğer bir renk ölçüm göstergesi olan $b^{*}$ parametresinde, $+b^{*}$ sarıy,$-b^{*}$ ise maviyi ifade etmektedir. Çiğ erişte örneklerinin $b^{*}$ değerleri 15.08-15.92 aralığında bulunmuş ve istatistiksel açıdan aralarında herhangi bir farklılığa rastlanmamıştır. incelendiğinde, $L^{*}, a^{*}$ ve $b^{*}$ değerlerinin sirasiyla $64.05-76.43,0.79-2.14$ ve $19.09-20.42$ aralığında olduğu görülmektedir. Pişirme işlemi ile $L^{*}$ değerinde artış gözlenmiştir ve erişte örnekleri içerisinde $L^{*}$ değerinde en büyük değişim BUPE örneğinde en az değişim ise SOPE ve YAPE örneklerinde tespit edilmiştir. $L^{*}$ değerinin aksine pişirme işlemi $a^{*}$ değerinde azalmaya neden olmuştur ve en fazla azalma yumurta akı proteini ile üretilen eriştede görülmüştür. Gerçekleşen bu durum pişirme işleminin eriştelerin kırmızılık değerinde azalmaya neden olduğunu göstermektedir. Öte yandan erişte örneklerinde sarılık renk göstergesi olan $b^{*}$ değerinin pişirme işlemi ile arttığı görülmüştür.

\section{Pişirme Özellikleri}

Erişte örneklerinin su bağlama, hacim artışı, suya geçen madde miktarı ve pişme süresi analiz sonuçları Çizelge 3 'de verilmiştir.

Farklı protein kaynaklarının erişte üretiminde kullanılması ile eriştelerin su bağlama özelliklerinin değiştiği belirlenmiştir $(p<0.05)$. 
En düşük su bağlama oranı \%92.17 değeri ile SOPE örneğinde, en yüksek değer ise $\% 117.86$ değeri ile YAPE'de belirlenmiștir. Düşük su bağlama yüzdesine sahip olarak bulunan bezelye ve soya proteinleri ile hazırlanmış eriştelerin pişirilme sonrasında en yüksek protein miktarına sahip ürünler olduğu tespit edilmiştir.

Çizelge 3. Eriştelerin pişirme özellikleri

\begin{tabular}{ccccc}
\hline & Su Bağlama (\%) & Hacim Artış1 (\%) & $\begin{array}{c}\text { Suya Geçen } \\
\text { Madde Miktarı } \\
(\%)\end{array}$ & $\begin{array}{c}\text { Pişme Süresi } \\
(\mathrm{dk})\end{array}$ \\
\hline SOPE & $92.17 \pm 0.10^{\mathrm{e}}$ & $150.00 \pm 0.17^{\mathrm{d}}$ & $4.20 \pm 0.27^{\mathrm{e}}$ & $11.41 \pm 1.03^{\mathrm{c}}$ \\
BUPE & $115.26 \pm 0.09^{\mathrm{b}}$ & $185.71 \pm 0.24^{\mathrm{c}}$ & $7.32 \pm 0.21^{\mathrm{c}}$ & $22.26 \pm 0.08^{\mathrm{a}}$ \\
PSPE & $98.39 \pm 0.12^{\mathrm{c}}$ & $200.00 \pm 0.19^{\mathrm{b}}$ & $10.73 \pm 0.04^{\mathrm{a}}$ & $11.49 \pm 1.12^{\mathrm{c}}$ \\
YAPE & $117.86 \pm 0.23^{\mathrm{a}}$ & $233.33 \pm 0.23^{\mathrm{a}}$ & $5.72 \pm 0.12^{\mathrm{d}}$ & $12.10 \pm 1.27^{\mathrm{b}}$ \\
BEPE & $96.91 \pm 0.04^{\mathrm{d}}$ & $150.00 \pm 0.14^{\mathrm{d}}$ & $8.40 \pm 0.09^{\mathrm{b}}$ & $9.30 \pm 0.06^{\mathrm{d}}$ \\
\hline
\end{tabular}

*Aynı sütundaki farklı küçük harfle belirtilen değerlerin istatistiksel olarak önemli ölçüde farklı olduğunu belirtmektedir. $\mathrm{p}<0.05$. ortalama \pm ;standart sapma

Bu durum analiz edilen örnek içinde daha düşük su miktarı varlığının protein değerinin artmasına neden olduğu şeklinde yorumlanabilir. Pişmiş eriştelerde su bağlama kapasitesi 1sı ile beraber nişasta ve proteinin şişme ve su bağlama özelliğini göstermektedir (Larrosa ve ark., 2016). Öte yandan su bağlama değerinin çok yüksek olması yumuşak, aşırı düşük olması ise sert ve pürüzlü yapıda erişteler elde edilmesini sağlamaktadır (Luo ve ark., 2015).

Örneklerin hacim artışı değerleri incelendiğinde en düşük hacim artışının \%150.00 oranı ile bezelye ve soya proteinleri ile üretilen eriştelerde olduğu görülmektedir. Sonrasında ise sırasıyla BUPE ve PSPE erişteleri yüksek hacim artışı oranlarına sahip olmuştur fakat en yüksek hacim artış1 YAPE eriştesinde \%233.33 değeri ile belirlenmiştir. Analiz sonucunda hayvansal proteinler ile üretilen eriştelerin daha yüksek hacim artışı değerlerine sahip oldukları görülmüştür.

Bir diğer pişirme özellikleri analizi suya geçen madde miktarının belirlenmesidir. Farklı protein kaynakları ile üretilmiş eriştelerin suya geçen madde miktarları istatistiksel açıdan birbirinden farklı olarak belirlenmiştir $(p<0.05)$. Soya proteini eklenerek üretilmiş eriştelerin suya geçen madde miktarları en düşük değerde $(\% 4.20)$ belirlenirken, peynir altı suyu proteini ile üretilen eriştede suya geçen madde miktarı en yüksek oranda (\%10.73) saptanmıştır. Pişirme suyuna fazla katı madde geçişi, üründe protein ve dolayısıyla glütenin azalması ile ilişkilendirilebilir (Rayas-Duarte ve ark., 1996). Bu noktada yapılan çalışmada kullanılan buğday proteinli eriştenin suya geçen madde miktarının yüksek orada belirlenmesi pişirme süresinin fazla olmasıyla açıklanabilir. Başka bir çalışmada ise yumurta ilavesinin eriştede su bağlama ve hacim artışı değerlerini artırdığı ve pişme süresini kısalttığı belirlenmiştir (Demi ve ark., 2010).

Eriştelerin protein kaynağı değişimi ile pişme sürelerinde meydana gelen değişimlerin belirlendiği analiz sonucunda en düşük pişme süresi $9.30 \mathrm{dk}$ ile bezelye proteini ile üretilmiş eriştede tespit edilmiştir. PSPE ve SOPE örneklerinin pişme süreleri birbirleri ile aynı olarak belirlenirken $(p>0.05)$ en yüksek pişme süresi $22.26 \mathrm{dk}$ ile buğday proteini eriştesinde gerçekleşmiştir. BUPE örneğinden sonra en yüksek pişme süresi $12.10 \mathrm{dk}$ olarak YAPE eriştesinde belirlenmiştir. Pişme süresinin gluten miktarı ile ilişkilendirildiği çalışmalarda gluten miktarındaki artışın pişme süresini uzattığ1 belirtilmektedir (Park ve Baik, 2004; Yao ve ark., 2020). 
Tekstürel Analizler

Farklı protein kaynakları ile üretilmiş eriştelerin tekstürel özelliklerinde meydana gelen değişimler çiğ erişte ve pişmiş erişte üzerinden incelenmiş ve sonuçları Çizelge 4'de gösterilmiştir.

Çizelge 4. Çiğ ve pișmiș eriște örneklerinin tekstür analiz sonuçları

\begin{tabular}{ccccc}
\hline & \multicolumn{2}{c}{ Çĭ̆ Erişteler } & \multicolumn{2}{c}{ Pişmiş Erişteler } \\
\cline { 2 - 5 } & S1k1lık (kg) & Toplam Kesme & Sertlik $(\mathrm{g})$ & $\begin{array}{c}\text { Yapışkanlık } \\
\text { Kuvveti (kg.sn) }\end{array}$ \\
\hline SOPE & $328.99 \pm 3.85^{\mathrm{b}}$ & $1517.61 \pm 2.73^{\mathrm{a}}$ & $7371.96 \pm 3.17^{\mathrm{c}}$ & $-89.65 \pm 3.92^{\mathrm{c}}$ \\
BUPE & $353.29 \pm 1.19^{\mathrm{a}}$ & $1127.06 \pm 1.90^{\mathrm{d}}$ & $9375.47 \pm 6.13^{\mathrm{b}}$ & $-123.52 \pm 5.80^{\mathrm{d}}$ \\
PSPE & $314.80 \pm 3.22^{\mathrm{c}}$ & $1218.10 \pm 4.01^{\mathrm{c}}$ & $5352.64 \pm 2.79^{\mathrm{d}}$ & $-83.06 \pm 6.50^{\mathrm{b}}$ \\
YAPE & $288.97 \pm 3.95^{\mathrm{d}}$ & $802.20 \pm 2.76^{\mathrm{e}}$ & $13616.12 \pm 7.13^{\mathrm{a}}$ & $-28.09 \pm 3.28^{\mathrm{a}}$ \\
BEPE & $329.74 \pm 4.87^{\mathrm{b}}$ & $1391.21 \pm 3.31^{\mathrm{b}}$ & $9697.20 \pm 1.55^{\mathrm{b}}$ & $-124.23 \pm 5.15^{\mathrm{d}}$ \\
\hline
\end{tabular}

*Aynı sütundaki farklı küçük harfle belirtilen değerlerin istatistiksel olarak önemli ölçüde farklı olduğunu belirtmektedir. $\mathrm{p}<0.05$. ortalama \pm ;standart sapma

Sik1lık analizi çiğ erişte örneklerinde ölçülen ilk parametre olmuştur. YAPE örneğinin sikılık değeri $288.97 \mathrm{~kg}$, BUPE eriştesinin ki ise 323.29 kg olarak belirlenmiştir. Diğer örnekler bu iki değer arasında sıkılık değerlerine sahip olurken soya ve bezelye ile üretilen eriştelerin s1kılık değerleri arasında fark bulunamamıştır ( $p>0.05)$. Çiğ eriştelerde yapılan bir diğer tekstürel değerlendirme ise toplam kesme kuvveti olmuştur. Toplam kesme kuvveti değerlendirmesinde sonuçlar 802.20-1517.61 kg.sn aralığında ve bütün erişte örneklerinde birbirinden farklı olarak belirlenmiștir $(p<0.05)$. Yumurta akı proteini ile üretilen erişte örneği sıkılık değerinde olduğu gibi toplam kesme kuvveti değerinde de en düşük sonuç veren örnek olurken soya proteini ise en yüksek toplam kesme kuvveti değerinin oluşmasına neden olmuştur.

Pişmiş eriştelerde tekstürel değerlendirmeler sertlik ve yapışkanlık açısından gerçekleştirilmiştir. Farklı protein kaynakları kullanılarak üretilen erişte örnekleri içerisinde en yumuşak erişte peynir altı suyu proteini ile üretilen örnek (5352.64 g) olarak belirlenirken en sert ürün ise yumurta akı proteini ile üretilen örnek (13616.12 g) olarak tespit edilmiştir. Buğday ve bezelye proteini ile üretilen örneklerin sertlik değerleri arasında istatistiksel açıdan herhangi bir fark bulunmamıştır (p>0.05). Sertlik değerinde olduğu üzere yapışkanlık değerlendirmesinde de buğday ve bezelye proteini ile üretilen eriştelerin yapışkanlık değerleri arasında fark bulunamamıştır $(p>0.05)$ ve en yapışkan örnekler olarak tespit edilmişlerdir. En az yapışkan örnek ise -28.09 g.sn değeri ile yumurta ak1 proteini ile üretilen erişte olmuştur. YAPE örneği diğer örneklerden oldukça farklı yapışkanlık değeri göstermiştir.

Erişte tarzı ürünlerde tekstür değerlendirmeleri arasında yer alan sertlik kriteri gluten ağ hakkında bilgi verirken, yapışkanlık değeri ise glütende bağlanma gücünün göstergesi olarak tanımlanmaktadır (Mudgil ve ark., 2016). Ayrıca iyi oluşmuş gluten ağının eriştelerde sertlik değerinde artışa neden olduğu çalışmalar sonucunda belirlenmiștir (Shiau ve Yeh, 2001; Guo ve ark., 2017). Öte yandan erişte örneklerinde sadece protein varlığı ve gluten miktarı değil ayrıca disülfür bağlarının miktarları ile proteinlerin yapısı (Kaur ve ark., 2016) ve moleküler ağırlıkları (Lu ve ark., 2016) gibi parametrelerden de etkilendiği belirlenmiştir. Glutensiz olarak üretilen pirinç makarnalarında kazein ve yumurta ak1 proteininin diğer katkı maddeleri ile oluşturduğu etkilerin belirlendiği çalışmada yumurta ak1 proteininin kazeine göre daha yapışkan ve yumuşak tekstürde makarnalar oluşturduğu tespit edilmiştir (Büyükbeşe ve ark., 2020). Ayrıca katkı maddesi ilavesi ile su bağlama kapasitesinin artması erişte türevi ürünlerde sertlik değerini ürün bünyesinde bulunan su 
miktarının artması nedeniyle azaltmaktadır (Şeker, 2020).

\section{Duyusal Analizler}

Duyusal değerlendirmeler erişte örnekleri için çiğ eriştelerde renk, kırılganlık ve görünüş, pişmiş eriştelerde ise renk, sertlik, yapışkanlık, çiğnenebilirlik, tat-aroma ve genel beğeni kriterlerinde yapılmıştır ve sonuçları Şekil 3'de gösterilmiştir. Çiğ erişte örneklerinde renk değerlendirmesi sonucunda panelistler tarafindan verilen en düşük puanı YAPE, en yüksek puanları ise SOPE ve PSPE örnekleri almıştır. Yumurta ak1 renk, görünüş ve kırılganlık parametrelerinin tamamında çiğ formunda en düşük puanı alan erişte olurken, bezelye ve buğday proteini ile üretilen örnekler görünüș değerlendirmesinde, PSPE örneği ise kırılganlık değerlendirmesinde en yüksek puanları alan ürünler olarak tespit edilmiştir. Pişmiş erişte örneklerinde ise genel beğeni değerlendirmesinde PSPE örneği en yüksek puana sahip olurken, BUPE eriştesi en az beğenilen örnek olarak belirlenmiştir. Bezelye, soya ve yumurta ak1 proteinleriyle üretilen erişteler genel beğeni kriterinden eşit puanlar almışlardır. Çiğ eriştelerde panelistler tarafından renk değerlendirmesinde farklilıklar belirlenmișken pişirme ișleminin farklılıkları ortadan kaldırdığ 1 görülmektedir. BUPE örneği haricinde tüm erişteler benzer puan değerlendirmelerine sahip olurken BUPE renk olarak en az tercih edilen ürün olmuştur.

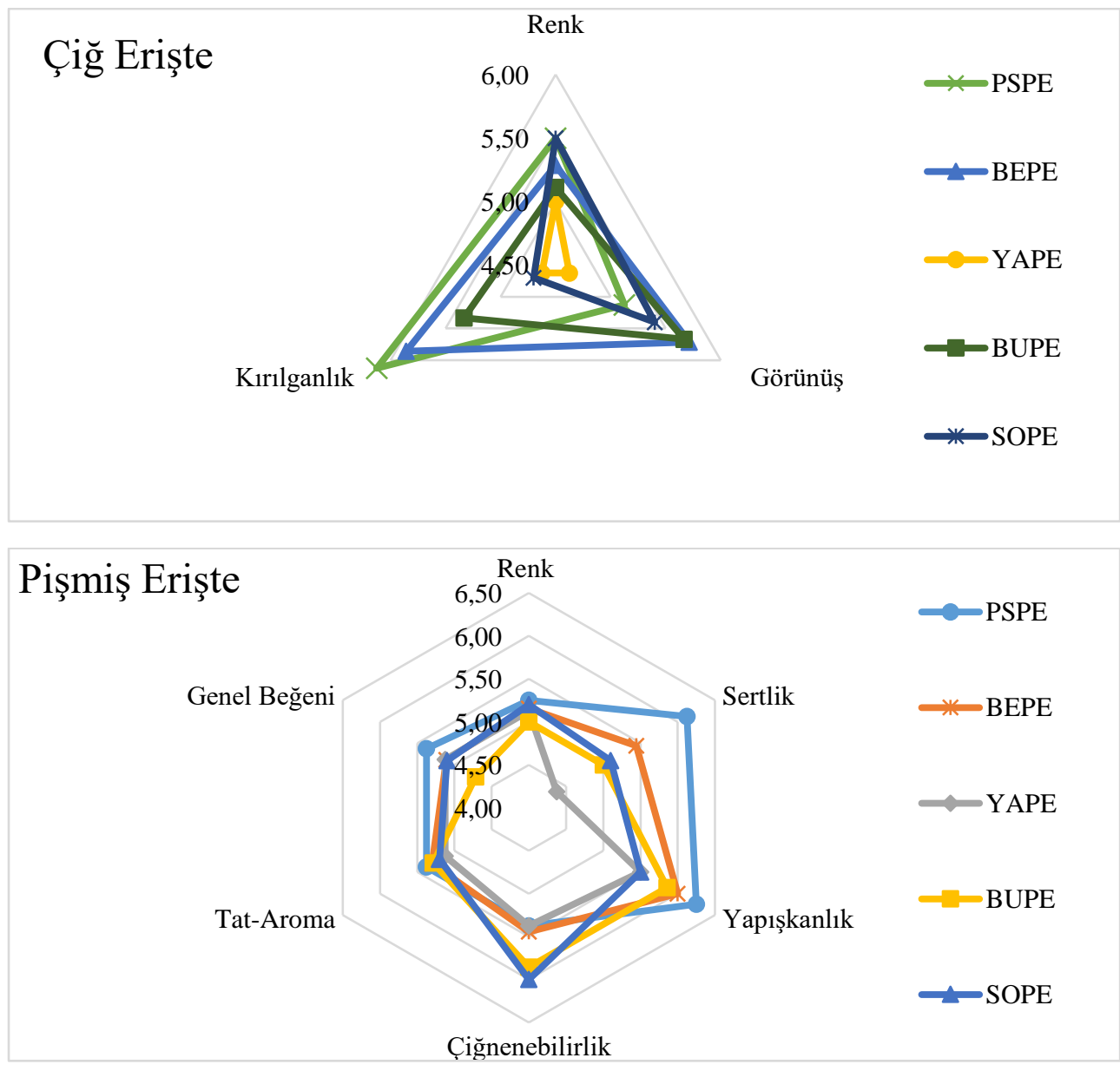

Şekil 3. Çiğ ve pişmiş eriştelerin duyusal analiz sonuçları

Duyusal değerlendirmeler sirasında panelistlerden duyusal formlarında yer alan 
kriterleri önem derecelerine göre sıralamaları istenmiş ve pişmiş erişte örneklerinde sırasıyla sertlik, çiğnenebilirlik, tat-aroma ve yapışkanlık kriterlerinin önemli bulunduğu belirlenmiştir. TOPSİS yöntemi ile elde edilen normalize ve ağırlıklandırılmış normalize karar matrisleri Çizelge 5'de verilmiştir. Karar matrisleri kullanılarak yapılan değerlendirmeler sonucunda elde edilen ideal çözüme uzaklık ve yakınlık değerleri Çizelge 6'da gösterilmiştir. İdeal çözüme göre yakınlık değeri $\left(\mathrm{R}_{\mathrm{i}}^{*}\right)$ baz alınarak yapılan önem siralaması sonucunda farklı protein kaynakları ile üretilen eriştelerin tercih edilme siraları PSPE, BEPE, SOPE, BUPE ve YAPE şeklinde belirlenmiştir. Seçilen 4 kriter ile yapılan çok kriterli karar verme uygulaması sonucunda en çok tercih edilen ürün peynir altı suyu tozu ile üretilen erişte olmuştur.

Çizelge 5. Eriştelerin TOPSİS değerlendirmesi için normalize ve ağırlıklandırılmış normalize karar matrisleri

\begin{tabular}{|c|c|c|c|c|c|c|c|c|}
\hline \multicolumn{5}{|c|}{ Normalize Karar Matrisi } & \multicolumn{4}{|c|}{ Ağırlıklandırılmış Normalize Karar Matrisi } \\
\hline & Çiğnenebilirlik & $\begin{array}{c}\text { Tat } \\
\text { Aroma }\end{array}$ & Yapışkanlık & Sertlik & Çiğnenebilirlik & $\begin{array}{c}\text { Tat } \\
\text { Aroma }\end{array}$ & Yapışkanlık & Sertlik \\
\hline PSPE & 0.47 & 0.47 & 0.47 & 0.52 & 0.16 & 0.09 & 0.02 & 0.22 \\
\hline BEPE & 0.43 & 0.45 & 0.44 & 0.46 & 0.14 & 0.09 & 0.02 & 0.20 \\
\hline YAPE & 0.47 & 0.45 & 0.41 & 0.37 & 0.16 & 0.09 & 0.02 & 0.16 \\
\hline BUPE & 0.46 & 0.40 & 0.43 & 0.42 & 0.15 & 0.08 & 0.02 & 0.18 \\
\hline SOPE & 0.42 & 0.46 & 0.47 & 0.45 & 0.14 & 0.09 & 0.02 & 0.19 \\
\hline
\end{tabular}

Çizelge 6. Eriştelerin TOPSİS değerlendirmesi sonucunda ideal çözüme yakınlık sıraları

\begin{tabular}{ccccc}
\hline Örnekler & $\mathrm{D}^{+}$ & $\mathrm{D}^{-}$ & $R_{i}{ }^{*}$ & Tercih Siras1 \\
\hline PSPE & 0.0000 & 0.0674 & 1.0000 & 1 \\
BEPE & 0.0310 & 0.0377 & 0.5489 & 2 \\
YAPE & 0.0643 & 0.0184 & 0.2227 & 5 \\
BUPE & 0.0460 & 0.0246 & 0.3479 & 4 \\
SOPE & 0.0358 & 0.0344 & 0.4901 & 3 \\
\hline
\end{tabular}

\section{Sonuç}

Erişte dünya genelinde ve ülkemizde oldukça fazla tüketilen ürünler arasında yer almaktadır. Yapılış tarzı ve ürün formülasyonuna katılan malzemeler gibi farklılıklar nedeniyle oldukça fazla çeşidi bulunan erişteye genellikle protein kaynağı olarak yumurta ilavesi yapılmaktadır ve protein kaynağı hamur ve ürün yapısında olumlu etkiler oluşturmaktadır. Bu çalışmada bezelye, soya ve buğdaydan oluşan bitkisel proteinler ve peynir altı suyu ve yumurta akından oluşan hayvansal proteinlerin eriștede olușturdukları etkiler, fizikokimyasal, pişirme, tekstürel ve duyusal özellikler üzerinden incelenmiştir. Duyusal değerlendirmeler için TOPSİS yöntemi kullanılmıştır. Protein çeşidi değişimi erişte özelliklerini etkilemiştir. Pişmiş ürünlerde yapılan protein analizinde soya ve bezelye proteini ile üretilen eriștelerde hacim artıș1 değerinin düşük olmasına bağlı olarak yüksek protein miktarları belirlendiği ve hayvansal proteinlerden üretilen ürünlerin protein değerlerinin benzer olduğu saptanmıştır. Protein çeşit farklılığı renk kriterlerinde de farklılıklara neden olmuştur ve pișirme işlemi ile beyazlık değerinde artış, kırmızılık değerinde azalma 
tespit edilmiştir. Pişmiş erişte örneklerinin sertlik ve yapışkanlık değerlendirmelerinde buğday ve bezelye aynı sonuçlarda elde edilirken en sert ürün yumurta ak1 proteini ile elde edilmiştir. TOPSİS değerlendirmesi sonucunda en beğenilen ürün PSPE eriştesi olurken YAPE örneği ise en az tercih edilen ürün olmuştur. Çalışma sonucunda yumurtaya alternatif olarak farklı protein kaynaklarının kullanılabileceği ve duyusal açıdan daha çok tercih edilen ürünler elde edilebileceği belirlenmiștir. Çalışmada bitkisel protein kaynaklarının kullanım olanaklarının araştırılması ile hayvansal ürün tercih etmeyen bireylerin tercih edebileceği erişteler elde edilmiștir. Öte yandan soya ve bezelye proteinleri kullanarak, protein değeri yüksek erişteler elde edebilmek mümkün olacaktır.

\section{Kaynaklar}

AACC. (2009) AACC International Approved Methods, AACC International Approved Methods.

Akillioglu, H.G., Yalcin, E. (2010) Some quality characteristics and nutritional properties of traditional egg pasta (Erişte). Food Sci Biotechnol 19:417-424.

Aktaş, K., Bilgiçli, N., Levent, H. (2015) Influence of wheat germ and $\beta$-glucan on some chemical and sensory properties of Turkish noodle. J Food Sci Technol 52:6055-6060.

Aktaş, K., Türker, S. (2015) Utilisation of dairy by-products and $\beta$-glucan in erişte production. Qual Assur Saf Crop Foods 7:809-818.

Alamprese, C., Casiraghi, E., Primavesi, L., Rossi, M., Hidalgo, A. (2005) Functional and rheological characteristics of fresh egg pasta. Ital J Food Sci 17:3-15.

AOAC. (2005) Official Methods of Analysis of AOAC International, Association of Official Analysis Chemists International.

Bilgiçli, N. (2009) Effect of buckwheat flour on cooking quality and some chemical, antinutritional and sensory properties of erişte, Turkish noodle. Int J Food Sci Nutr
60:70-80.

Bilgiçli, N., Demir, M.K., Ertaş, N., Herken, E.N. (2011) Effects of gluten and emulsifier on some properties of erite prepared with legume flours. Int J Food Sci Nutr 62:63-70.

Büyükbeşe, D., Emre, E.E., Kaya, A. (2020) Farkl1 oranlarda gam, protein ve emülgatör kullanımı ve jelatinizasyonun pirinç makarnas1 kalitesine etkisi. Akad Glda $18: 45-63$

Çelik, İ., Pozan, K. (2020) Kavun çekirdeği tozunun eriştenin bazı özelliklerine etkisi. Glda / J Food 45:907-916.

De Zorzi, M., Curioni, A., Simonato, B., Giannattasio, M., Pasini, G. (2007) Effect of pasta drying temperature on gastrointestinal digestibility and allergenicity of durum wheat proteins. Food Chem 104:353-363.

Demi, B., Bilgiç, N., Eldün, A., Demi, M.K. (2010) Effects of chickpea flours and whole egg on selected properties of erite, Turkish noodle. Food Sci Technol Res 16:557-564.

Dirim,S. N., Çalışkan, G. (2017) Enhancement of the Functional properties of home-made style Turkish noodles (eriște) with the addition of fresh mints. J Food Phys 30:414.

Dogan, M., Aslan, D., Aktar, T., Goksel Sarac, M. (2016) A methodology to evaluate the sensory properties of instant hot chocolate beverage with different fat contents: multicriteria decision-making techniques approach. Eur Food Res Technol 242:953966.

Eyidemir, E., Hayta, M. (2009) The effect of apricot kernel flour incorporation on the physicochemical and sensory properties of noodle. African J Biotechnol 8:85-90.

Gökdalay, M.H. (2009) Havaalanlarının performans analizinde bulanık ölçütlü karar verme yaklaşımı. Ístanbul Tek Üniversitesi Mühendislik Derg 8:157-168. 
Guo, X.N., Wei, X.M., Zhu, K.X. (2017) The impact of protein cross-linking induced by alkali on the quality of buckwheat noodles. Food Chem 221:1178-1185.

Kaur, A., Shevkani, K., Katyal, M., Singh, N., Ahlawat, A.K., Singh, A.M. (2016) Physicochemical and rheological properties of starch and flour from different durum wheat varieties and their relationships with noodle quality. J Food Sci Technol 53:2127-2138.

Koca, I., Tekguler, B., Yilmaz, V.A., Hasbay, I., Koca, A.F. (2018) The use of grape, pomegranate and rosehip seed flours in Turkish noodle (erişte) production. J Food Process Preserv 42:13343.

Kruger, J,E., Anderson, M,H., Dexter, J.E. (1994) Effect of flour enrichment on raw Cantonese noodle color and texture. Cereal Chem 71:177182.

Lai, H.M. (2002) Effects of rice properties and emulsifiers on the quality of rice pasta. $\mathrm{J}$ Sci Food Agric 82:203-216.

Larrosa, V., Lorenzo, G., Zaritzky, N., Califano, A. (2016) Improvement of the texture and quality of cooked gluten-free pasta. $L W T$ Food Sci Technol 70:96-103.

Levent, H., Yeşil, S. (2019) The effects of drying methods on the quality of Turkish noodle with legume flours. Gida 44:1161-1173.

Levent, H. (2017) Effect of partial substitution of gluten-free flour mixtures with chia (Salvia hispanica L.) flour on quality of gluten-free noodles. J Food Sci Technol 54:1971-1978.

Li, M., Zhu, K.X., Guo, X.N., Brijs, K., Zhou, H.M. (2014) Natural additives in wheatbased pasta and noodle products: Opportunities for enhanced nutritional and functional properties. Compr Rev Food Sci Food Saf 13:347-357.

Lu, Z.H., Donner, E., Yada, R.Y., Liu, Q. (2016) Physicochemical properties and in vitro starch digestibility of potato starch/protein blends. Carbohydr Polym 154:214-222.
Luo, L.J., Guo, X.N., Zhu, K.X. (2015) Effect of steaming on the quality characteristics of frozen cooked noodles. LWT - Food Sci Technol 62:1134-1140.

Mudgil, D., Barak, S., Khatkar, B.S. (2016) Effect of partially hydrolyzed guar gum on pasting, thermo-mechanical and rheological properties of wheat dough. Int J Biol Macromol 93:131-135.

Öncel, E., Demir, M.K. (2019) Farklı oran ve kombinasyonlarda kullanılan yalanc1 tahıl unlarının erişte özelliklerine etkisi. Akad Gida 17:468-475.

Özkaya, B., Özkaya, H., Buyukikiz, E. (2001) The cooking properties of eriste (Turkish noodle) produced by traditional methods. Getreide Mehl und Brot 55:120-125.

Park, C.S., Baik, B.K. (2004) Relationship between protein characteristics and instant noodle making quality of wheat flour. Cereal Chem 81:159-164.

Petitot, M., Brossard, C., Barron, C., Larré, C., Morel, M.H., Micard, V. (2009) Modification of pasta structure induced by high drying temperatures. Effects on the in vitro digestibility of protein and starch fractions and the potential allergenicity of protein hydrolysates. Food Chem 116:401412.

Rayas-Duarte, P., Mock, C.M., Satterlee, L.D. (1996) Quality of spaghetti containing buckwheat, amaranth, and lupin flours. Cereal Chem 73:381-387.

Şeker, İ. T. (2020) Tahıl Teknolojisinde Tekstür, Göksel Saraç, M. (Ed.), Gıdalarda Tekstür. Nobel Yayınevi, Ankara, pp. 63-73.

Shiau, S.Y., Yeh, A.I. (2001) Effects of alkali and acid on dough rheological properties and characteristics of extruded noodles. $J$ Cereal Sci 33:27-37.

Tuncel, N.Y., Kaya, E., Karaman, M. (2017) Rice bran substituted Turkish noodles (Erişte): Textural, sensorial, and nutritional properties. Cereal Chem 94:903-908. 
Bitkisel ve Hayvansal Proteinlerin Eriştenin Tekstürel ve Duyusal Özelliklerine Etkisi

Veldhorst, M., Smeets, A., Soenen, S., Hochstenbach-Waelen, A., Hursel, R., Diepvens, K., Lejeune, M., LuscombeMarsh, N., Westerterp-Plantenga, M. (2008) Protein-induced satiety: Effects and mechanisms of different proteins. Physiol Behav 94:300-307.

Woo, K.S., Seib, P.A. (2002) Cross-linked resistant starch: Preparation and properties. Cereal Chem 79:819-825.

Yao, M., Li, M., Dhital, S., Tian, Y., Guo, B. (2020) Texture and digestion of noodles with varied gluten contents and cooking time: The view from protein matrix and inner structure. Food Chem 315:126230. 
Bitkisel ve Hayvansal Proteinlerin Eriştenin Tekstürel ve Duyusal Özelliklerine Etkisi 